\title{
Montage, DaDa and the Dalek: The Game of Meaning in Higher Education
}

Sandra Abegglen

University of Calgary, Canada

\section{Tom Burns}

\section{London Metropolitan University, United Kingdom}

\author{
Sandra Sinfield \\ London Metropolitan University, United Kingdom
}

\begin{abstract}
This paper argues for visual playfulness in Higher Education learning and teaching practice. We offer a case study example of how we, the authors of this paper, have incorporated creativity into our teaching - the Facilitating Student Learning module, the first module in the Postgraduate Certificate in Learning and Teaching in Higher Education. We outline how we used 'visualising to learn' and what learning resulted from our visualisation practices. With our staff learners, we found that visual play gave them the freedom to experiment, to question and to progress; important in these supercomplex, uncertain times. Our desire was not to 'fix' or train academic staff, but to give them the space and tools to become liberatory professionals on their own terms and in their own ways so they can support their students to also become academic without losing themselves in the process. We propose that what is needed are methods and methodologies that enable learners - staff and students - to evolve and transform as they co-construct their knowledge in ludic ways. We incorporate images of the representations that our participants have made of themselves, of their students and of Higher Education systems to illustrate the challenges and possibilities of visual learning - and of creative staff development practice in general - and invite the reader to engage dialogically with them also to see what meanings they might make of them.
\end{abstract}

Keywords: Visual Practice; Visualisation; Creativity; Academia; Higher Education; Educational Development; Adult Learners 


\section{Introduction: Visual Metaphors and Visual Practice in Learning and Teaching}

Art has begun to feel not like a respite or an escape, but a formidable tool for gaining perspective on what are increasingly troubled times (Laing, 2020).

Playful, creative and visual learning and teaching approaches have found their way into Higher Education (HE) - and into classrooms (James and Neranzti, 2019; Nerantzi, 2016). This is not 'dumbed down' teaching nor is it 'dumbed down' learning: this is 'serious business' (Parr, 2014). Harnessing the ludic (Sinfield, Burns and Abegglen, 2019) for empowering practice has been shown to enhance our teaching and the learning experience of students (James and Nerantzi, 2019; Abegglen, Burns and Sinfield, 2018; Burns, Sinfield and Abegglen, 2018). Play gives students the freedom (Huizinga, 1949) to experiment, to question and to progress. This is important in these supercomplex (Abegglen, Burns, Maier and Sinfield, 2020b) lean and mean times (Giroux, 2014) where the present is uncertain and the future even more so. Teaching and learning supposedly fixed 'forms of knowledge' (Hirst, 1974) and developing 'traditional' skills are no longer sufficient (if they ever were). What is needed are methods and methodologies that enable students to evolve and transform as they co-construct their knowledge in ludic ways (Sinfield, Burns and Abegglen, 2019). What is called for is an epistemological shift: developing a praxis that consists of ethics, aesthetics, production and explanation - the bringing together of theory and practice (Bernstein, 2001) - and for us this starts with visual play. For it is in play and only in playing that the individual is fiercely alive, able to use the whole personality, creatively (Winnicott, 1971). It is a medium for developing - and growing.

In this paper, we discuss how we incorporate play and visual playfulness into our teaching and learning practice, especially in our Facilitating Student Learning (FSL) module, the first module in the Postgraduate Certificate in Learning and Teaching in Higher Education (PGCert) course and the Masters in Learning and Teaching in Higher Education (MALTHE) programme at London Metropolitan University (UK). In FSL, we use these creative and ludic practices to deepen the learning experiences of our staff learners, to make space for them to think, see and 'be' differently - and to increase the repertoire of creative learning, teaching and assessment strategies that they can embody in their own practices. In the process, we place a strong emphasis on developing the 'self', as 'knowing' oneself is a key attribute for being able to develop (Rogers, 1961) and to move on to the precarious ground of teaching, as opposed to operating in places of 'best practice' instruction. 'Best practice' or 'safe certainty' has been shown to fall short in a marketised education system - as it has in other sectors (Care, Financial, Health) in Western democracies that have failed to provide the requisite care, stability and success, and as exhibited most recently in various

International Journal of Management and Applied Research, 2020, Vol. 7, No. 3 
inabilities to adequately and fairly address the Covid-19 pandemic. Arguably we, universities, tutors and students, need to acknowledge and embrace 'radical uncertainty' (Kay and King, 2020) - our own and that of our disciplines - to be able to adapt and then (successfully) learn and support.

Here we outline the visual and creative approaches we use in our teaching with staff learners: we tell the story of 'visualising to learn' and 'learning to visualise'. We showcase the work we have undertaken and discuss the artefacts produced along the lines of a Creative Analytical Process (CAP) ethnography (Richardson and St Pierre, 2005) - as a promotion of a more creative HE searching for increased social justice.

\section{Facilitating Student Learning: Visualising the Self, the Student and the University}

...the image possesses an uncanny power. It can travel where the body can't. It migrates and strays, taking up permanent residence in the mind, revealing what - who - has been forcibly excluded from sight (Laing, 2020).

At this time, all staff new to our London-based University have to undertake a formal teaching qualification. This can be as fundamental as attending our core FSL module, successful completion of which confers Associate Fellowship of AdvanceHE, the Professional Standards body of the Higher Education sector. It can also involve undertaking the full PGCert which comprises three modules that cover student learning; assessment and feedback; and curriculum evaluation and development. Completion of the PGCert confers full Fellowship of AdvanceHE - and we also hope it acts as a further springboard not just to participation in the MA (which consists of the PGCert modules, further learning opportunities and a Dissertation or Project), but also for our staff, as scholarly professionals, becoming more aware of their practice as 'action research'.

This academic year, 2019/2020, we had 27 staff enrolled in FSL, across the disciplines: architecture to nutrition, international relations to sports science, social sciences to computing. Many of our participants have been teaching for many years in other institutions and countries. Typically, all our participants have multiple responsibilities in the University, they are time poor and under constant pressure. They are, and they 'feel' that they are already proficient tutors and lecturers. This makes attendance of our modules and courses not always their first priority nor is it always what they feel they 'need' or 'would like'. Despite potential resistance and the pressures they experience, we definitely want our participants to engage critically, mindfully and reflectively with our module - using it as a lens to interrogate their own ways of 'doing'. We aim to 'make strange' (Shklovsky, 1990) their taken-for-granted

International Journal of Management and Applied Research, 2020, Vol. 7, No. 3 
notions of education; to move to a place of 'safe uncertainty' (Mason, 1993) - using chance, collaboration, visual practices and language as a catalyst for creativity (MoMA, no year).

\section{How we Encourage our Students to Become Creative}

A key aspect of our FSL module is that we 'immerse' participants in playful and creative learning; we facilitate an opening up and an imagining of what they, the education system and their students could be (see also McIntosh, 2010; McIntosh, 2007). To initiate this process, we ask them at the very beginning of our module to make a collage representing themselves or themselves as teachers - which may or may not be the same thing. We use this as an opportunity for them to 'get' or 'be' creative as they reflect and surface their thinking through pictures (Berger, 1972): to construct meaning visually. Participants develop their self representation in class, using the magazines, scissors and glue provided. Once the collages have been made, people discuss them in pairs - starting with the 'non-maker' saying what they 'see' in the image of their peer as the starting point for 'rich' conversations. We then ask participants to move around, so they have more conversations with different people in the room, introducing themselves, and connecting in the process.

For the second class, we ask our staff learners to return having completed one of two alternative visual tasks: they can 'make' an extended, more elaborate representation of themselves in collage, combined if they wish with any other visual medium - or they can create a more abstract, 3D, multimodal artefact representing a 'typical student' (although there is no such thing). Staff learners showcase their visual and 3D artefacts of their self and student representations in an in-class exhibition - a semi-safe space, with their peers and us, the instructors, as the audience. Staff learners decide how to showcase their artefacts and where and how to pin them up or where and how to display them in the room. This means, learners take the responsibility for their work and of the exhibition as a whole. This is deliberate as we want them to experience agency and to take ownership of their learning.

Following on from the exhibition, staff learners are asked to make a representation of either the present HE system or an ideal or utopian HE using material from our Dalek of Resources (Figure 1), our fictional extraterrestrial mutant modelled on those portrayed in the British science fiction programme Doctor Who. The staff have been 'imprisoned' in 'nuclear bunkers' (viz. Post-apocalyptic simulation: https://learning.londonmet.ac.uk/take5/simulations.html) in the first week of the module. In this second 'role-play' session, we allow staff learners out to rebuild the world, starting with the building of a representative HE system. For this, we use the resources on our Dalek (perhaps our own embodiment of HE?). The Dalek is loaded with wool, cardboard tubes, multicoloured confetti, paper clips and paper cups. There

International Journal of Management and Applied Research, 2020, Vol. 7, No. 3 
are sponges and pegs and chopsticks - blu-tack, duct tape and glue. There are pots of pins, and bits and bobs from the DIY store. There are felt-tips, pencils, crayons - and paint. Participants are asked to use whatever materials they like or consider useful for their representation. We encourage them to 'create' a type of hyper-reality: that brings together, in oscillation, how they either perceive or imagine the post-apocalyptic HE world - something which is now more important than ever with current world-wide developments.

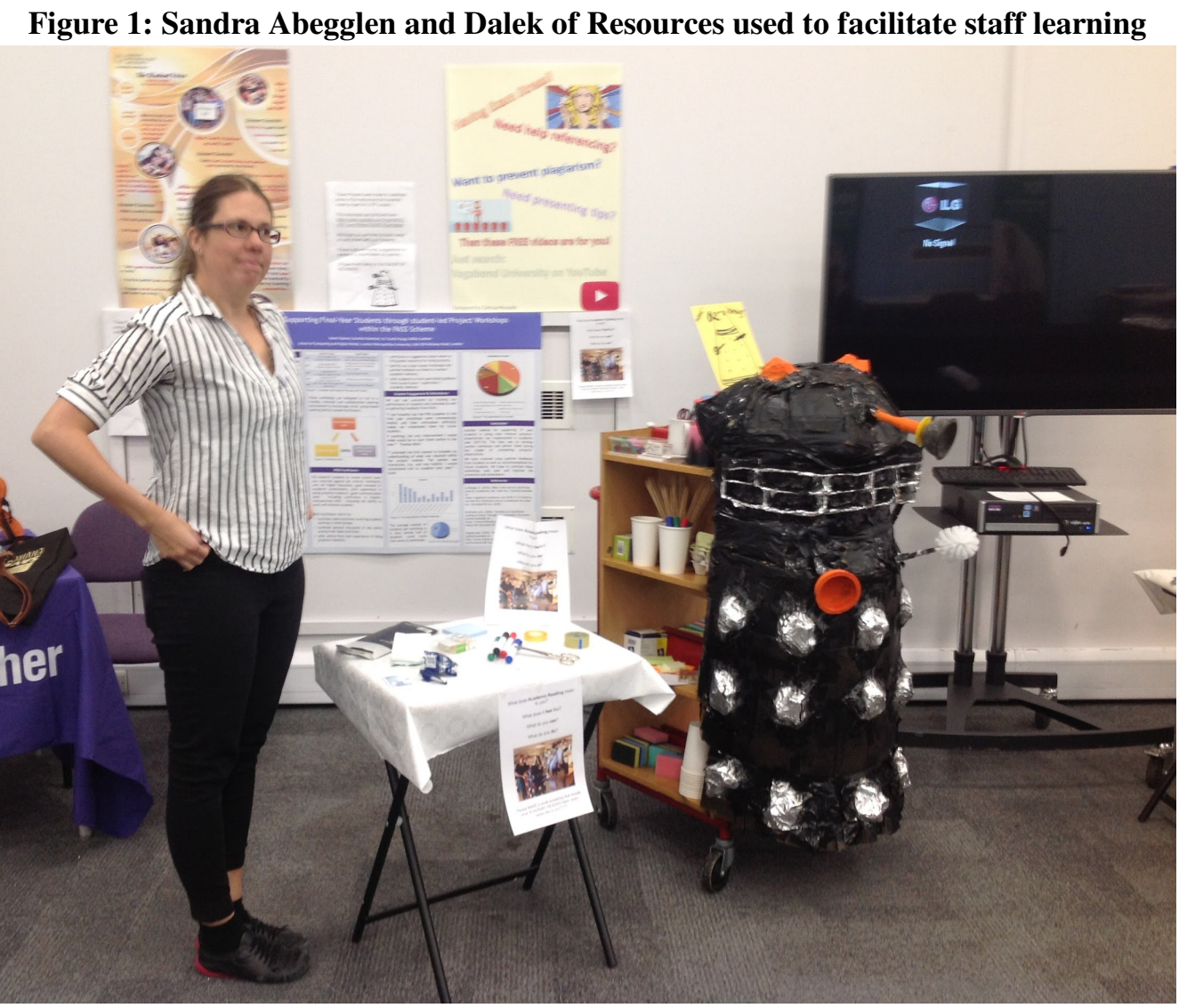

Each group has to 'present' their imagined post-apocalyptic HE system and the rationale behind it to their peers who cluster around, ask questions - and applaud. This discussion surfaces and recognises the values, hopes and aspirations - or preconceptions - to which they have given form. They recognise their common humanity and their diversity - not in terms of age, ethnicity, class and gender necessarily - but of their epistemic and their personal selves. We incorporate into this also reflective practice (Schön, 1983) and reflective writing (Elbow 1998). All our staff learners are encouraged to keep and share their own blog to engage with their own learning and teaching practice and with that of their peers. These opportunities for reflection and meta-reflection are part of the participants' professional development as they take ownership of who they are, what they know and the theoretical perspectives

International Journal of Management and Applied Research, 2020, Vol. 7, No. 3 
they are encountering. It is also important to help them realise that they have engaged in purposeful activity.

At the end of this second session therefore we have brought into view visions of the teaching self, the student self and the institutional 'self' - and have discussed how we might make HE better fit the human beings that it is ostensibly designed to accommodate: a humane education (Abegglen, Burns, Maier and Sinfield, 2020a). These visual practices surface the utterances and the voices that constitute the self in this context. The production of the collages and the 'universities', from the almost chance encounters with magazine images and random resources, offer a surrealist encounter with the self - with the unconscious. This is a production and reconstitution the visual as a search for authenticity and re-imagining of other selves (Bateson, 2000); an opportunity to build new narratives.

\section{The Thing Itself Always Escapes (Evaluation)}

Art is a place ... where ideas and people are made welcome. It's a zone of enchantment as well as resistance, and it's open even now (Laing, 2020).

Our evaluation of the success of our visualising techniques for critical learning is undertaken not by analysis of participant reflections on these activities nor from inclass surveys or by interrogating their reflective logs or blogs; although we could do that. Our focus here is to share and discuss some of the visual representations that our staff made of themselves, of students and (collaboratively) of HE Institutions (HEI). This is where we do not want to fall into the epistemology traps of positivist methodologies (and some qualitative ones, too). We do not want to make 'over assumptions' about the 'whole' based on the 'parts' (Vygotsky in Moen, 2006) because the parts must stand with the whole (the students with the staff, the staff with the students, students and staff with the universities, the universities with students and staff) to avoid a reductionism that is rendered inadequate in an era of supercomplexity (Abegglen, Burns, Maier and Sinfield, 2020b) and radical uncertainty (Kay and King, 2020). Thus, we are sharing some of the representations of self, student and institution for readers to consider and think about.

First, we are focusing on staff learners' representations of themselves, as teachers. Second, we show staff representations of 'typical' students. Third, we present staff representations of universities (or HEIs), which they made collaboratively in class. These representations are taken from participants' blogs, which are publicly accessible to everyone interested in their work. We have chosen images from across several module runs to ensure confidentiality. This means, the representations shown here stem from several different year groups attending FSL.

International Journal of Management and Applied Research, 2020, Vol. 7, No. 3 


\subsection{Staff learners' self portraits:}

Figure 2: Staff Self Portrait 1

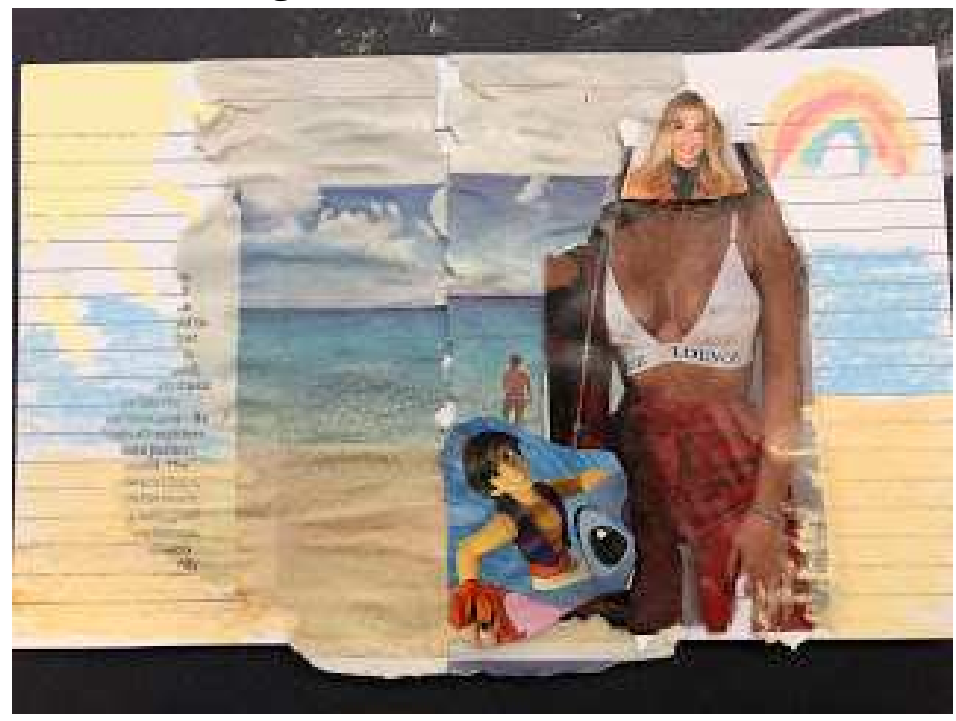

Figure 3: Staff Self Portrait 2

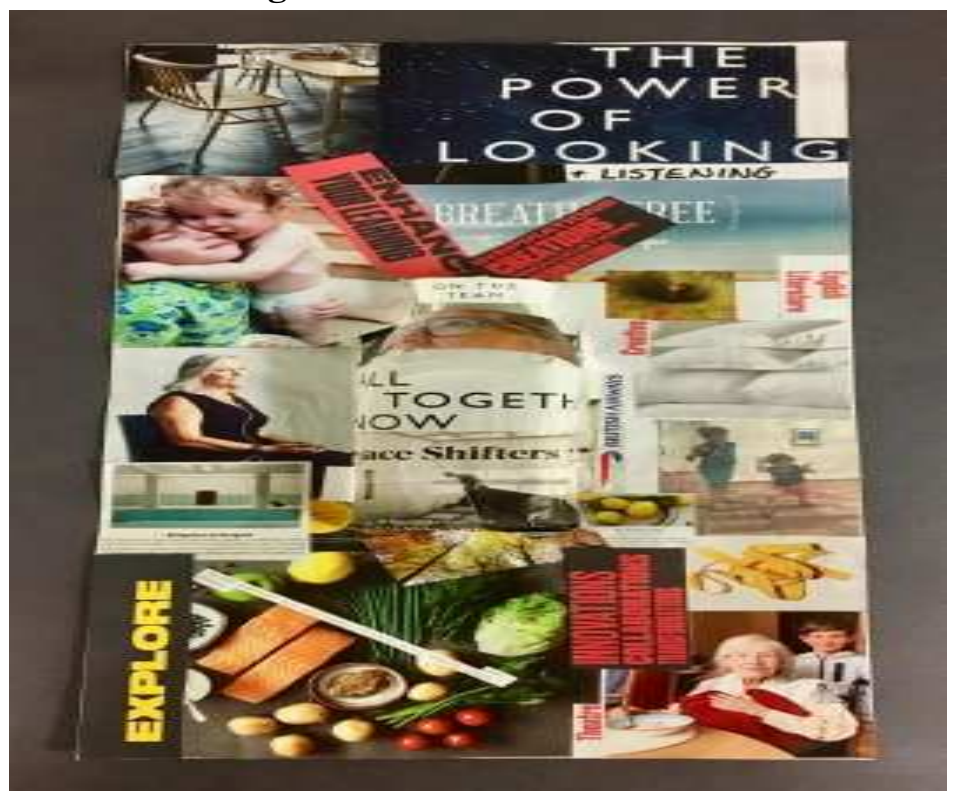

International Journal of Management and Applied Research, 2020, Vol. 7, No. 3 


\subsection{Staff learners' Representations of Students (or a Student):}

Figure 4: Representation of a Student 1

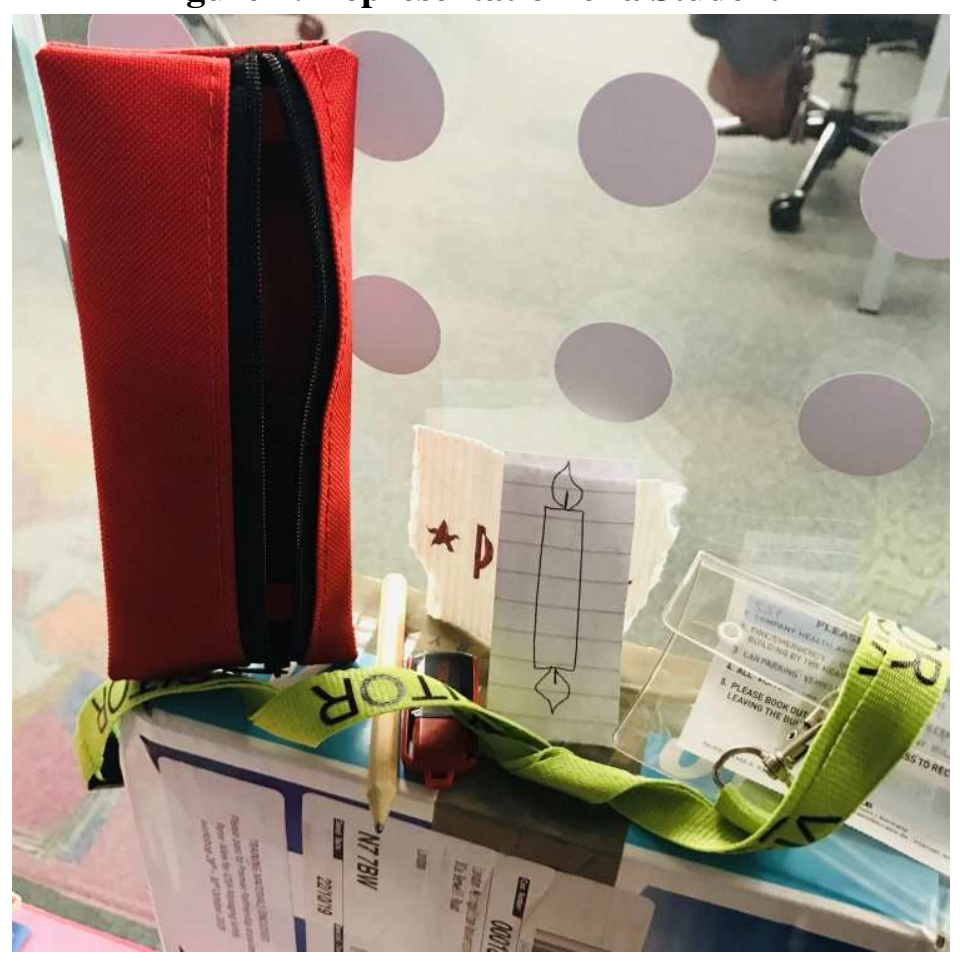

Figure 5: Representation of a Student 2

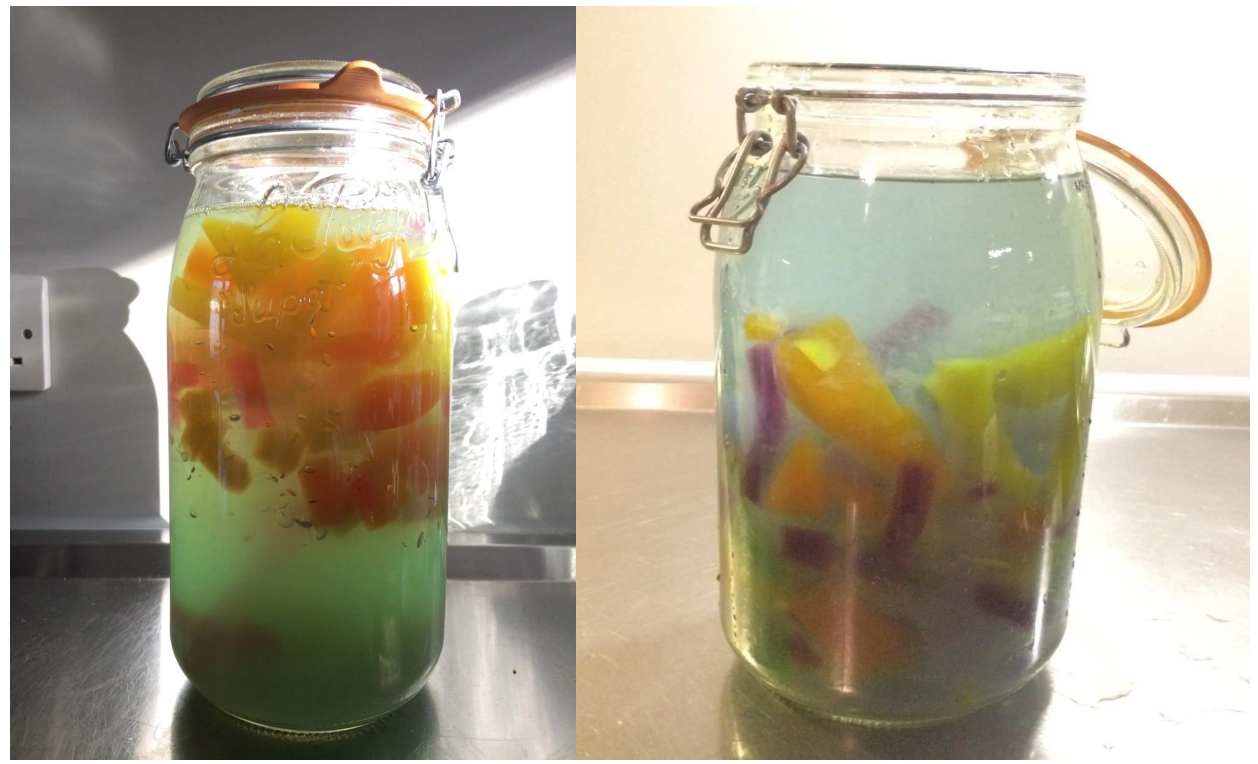

International Journal of Management and Applied Research, 2020, Vol. 7, No. 3 
4.3. Staff Learners' Representation of a (Real or Imagined) University or Higher Education System:

Figure 6: Representation of a University/Higher Education System 1

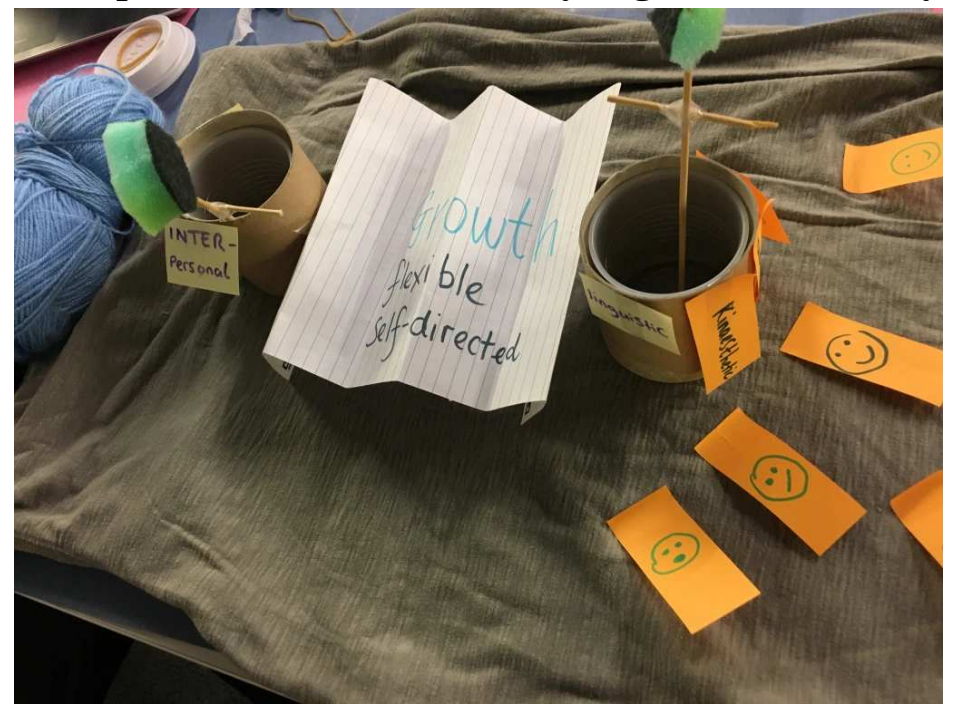

Figure 7: Representation of a University/Higher Education System 2

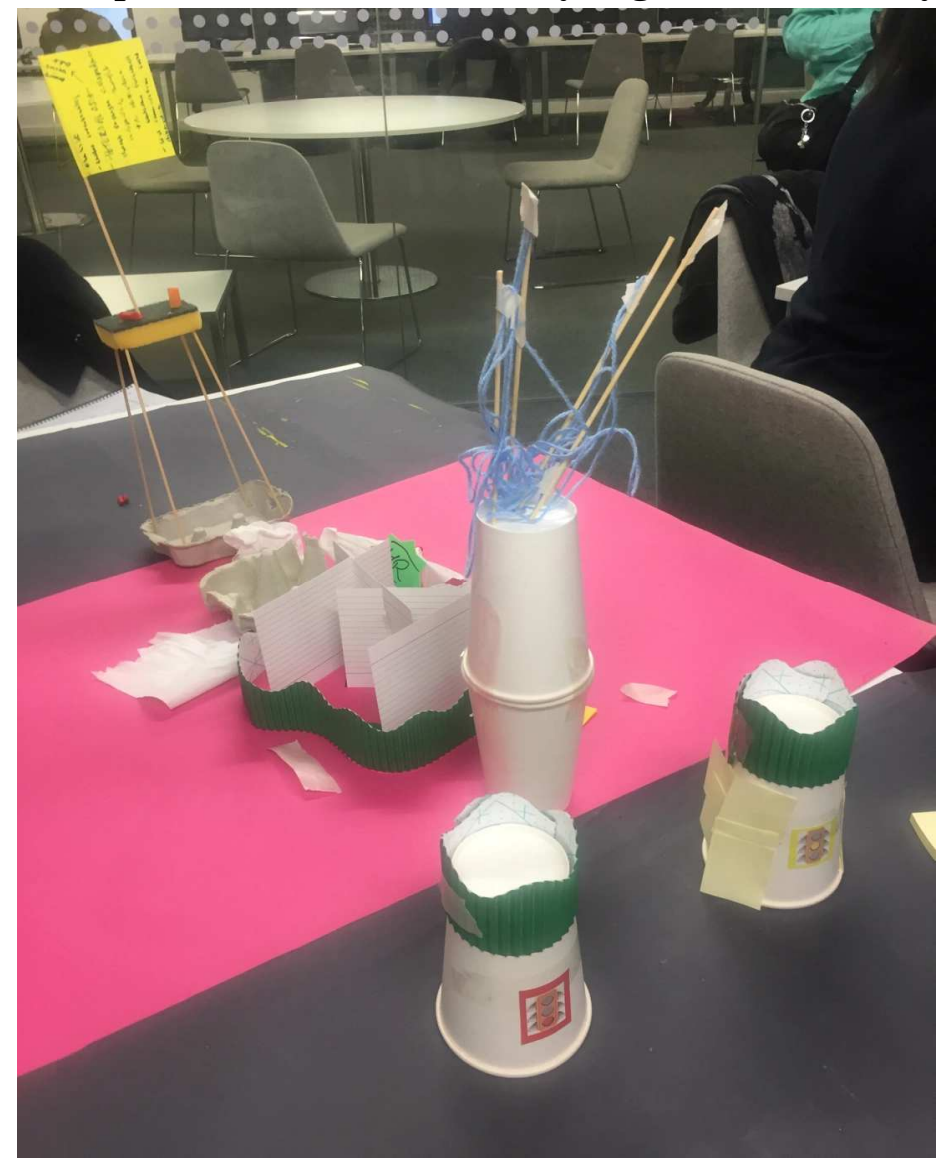

International Journal of Management and Applied Research, 2020, Vol. 7, No. 3 
Figure 8: Representation of a University/Higher Education System 3



Figure 9: Representation of a University/Higher Education System 4

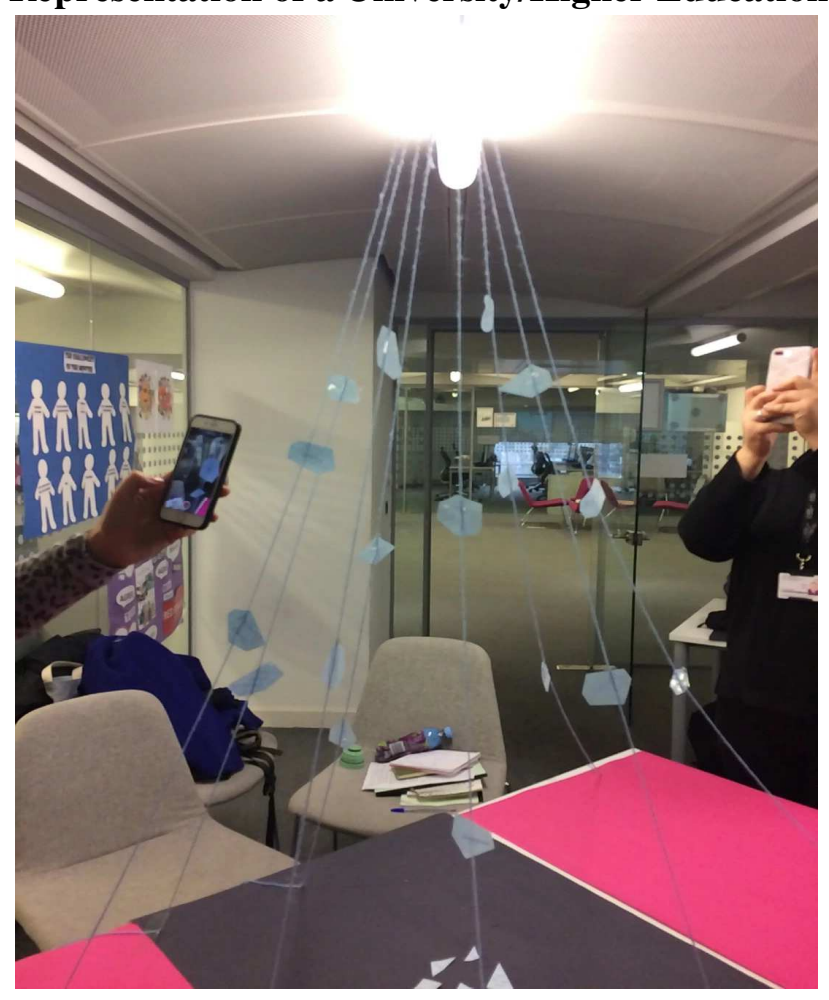

International Journal of Management and Applied Research, 2020, Vol. 7, No. 3 


\section{Discussion}

Hope is the precursor to change. Without it, no better world is possible.

Laing (2020)

Looking at these representations poses a few immediate questions: How might the 'jelly student' (Figure 5) feel when entering HE? How does he or she fit into, for example, a university that is built out of Lego as a high straight, impregnable tower (Figure 8) - with only space for a very few at the top? That tower is built on successive strands of successful education foundations: nursery, primary, secondary... The majority of our students do not enter our university with such solid educational foundations - and thus our task is to make sure that they are not further diminished by this. Typically, we attempt to de-stabilize that very tower - we de-school (Illich, 1972) and un-school (Holt, 1976) so that the students can critique and interrogate the system that they are entering and create their own selves as they become academic in their own terms. In our current crisis, the only response from the Lego tower appears be to add an antenna and broadcast content *at* students, rather than develop interactive and engaging practice with them.

Every year, staff also build more optimistic representations of HE (Figures 6 and 9) where there is a positive 'outlook'; porous and amorphous structures with flexible, welcoming learning and teaching spaces and 'shelters' that acknowledge and accommodate the people that enter. These HEIs provide for the student that is ready to learn, arriving with a pencil case and a box of tools (Figure 4), but also those that are less sure of their new undertaking (Figure 5). These open and flexible universities allow a weaving in and out of people and of ideas. For example, the construction in Figure 9 stands tall like the Lego tower but with fewer walls and borders: everyone is welcome here and the institution is prepared to shift to accommodate. This is in complete contrast to the HE that is gated and restricted, with a watchtower controlling entry and exit (Figure 7). In this system, only a few are welcomed. Even those that 'make it' encounter blank walls topped with spikes. Beyond that is a gated maze, the ground littered with more upended spikes. The few that 'survive' this test must pass yet another, even more rigorous, inspection before they leave. The learning - and the teaching - in this system is more than challenging. It is occult, mysterious and dangerous. It requires from students - and teachers - super fitness and strength (Figure 2). And, no wonder one may wish sometimes to be elsewhere, at the beach, escaping from it all. In this context, how can anyone bring the whole self into the classroom (Figure 3)? Teachers - as do students - have personalities and lives that consist of so much more than their learning and teaching selves. How can one use personal traits, responsibilities and interests in a professional context? We definitely suggest that looking at oneself and reflecting on the different aspects of education is a starting point - making visual what stays normally hidden and is untold.

International Journal of Management and Applied Research, 2020, Vol. 7, No. 3 


\section{Implications for Praxis}

Comfort the troubled and trouble the comfortable.

By Mike Bearsley in BBC Radio5 Live, 22 April (2020)

We would argue that these visual and creative activities, here undertaken with staff, would also prove fruitful as student-facing activities in any discipline in their current form. For example, these activities could be used as they are with new students - in class or in induction week. Students could produce self portraits of themselves as putative students - and collaborative representations of 'university'. If you felt really brave, you could also ask them to make models of a 'typical' tutor - and then deconstruct those together. These would reveal to themselves - and to tutors - what the new students are thinking about $\mathrm{HE}$ at their point of entry. These visual representations can lead to useful discussion of the what, why and how of study. They can also lead to discussion of the what, why and how of being an engaged and successful student. These can be built on over time. For example, they can seed small pieces of reflective writing that many students are asked to produce these days in their first few weeks at university or they can seed a first piece of qualitative research into successful study practices or attitudes to study.

These activities can be developed even further: students can be asked to make representations (purely visual or 3D) of different concepts or models that are covered in courses and modules. Business students, for example, could make representations of different organisational structures - and of a particular issue they are facing - perhaps then changing the representations to solve the 'problem' set. In any discipline, students can make visual representations rather than writing an essay or producing the traditional academic poster to display their research findings (Burns, Sinfield and Abegglen, 2018). Students can also prepare collages to reflect on learning or to prepare for an assignment; and we have asked students to utilise resources, as on our Dalek, to make revision games for other students as a very interactive way to prepare for their exams - and this could even be developed as an alternative 'exam'.

\section{Taking Down the Lego Tower: Effectiveness of Visual Methodologies in the Game of Meaning in Higher Education}

We are used to horrible things and stop fearing them. We get used to beautiful things and stop enjoying them. We get used to people and stop experiencing them as personalities. Art is a means to make things real again (Shklovsky, 2015, p. 151).

Conceiving of PGCert modules or staff 'training' as a form of re-educating staff does nothing to tackle the overarching and problematic narratives of education with which they are also struggling, nor enhance their teaching practice. Rather they/we need

International Journal of Management and Applied Research, 2020, Vol. 7, No. 3 
spaces that allow: "a feeling of being inducted back into hope, a restoration of faith" (Laing, 2020). We therefore recommend moments of play, of creation and of experimentation. Giving expression to the conversations and interactions in the classroom but also to those voices that constitute who we are in any given context. Our use of visual practices allowed for the creation of new, more positive and hopeful narratives of learning and teaching, for without these educational narratives we do not exist (Polkinghorne in Moen, 2006). We believe that we need more creative and emancipatory practices - for staff and students - that seed multimodal engagement with learning and teaching; imagining what is possible; a moving beyond. We are particularly keen to take down the hostile and impenetrable tower of HE, to tear down the watchtowers and remove the gatekeepers: to build a village of learners that have equal participation and say in the process. Our staff's visual practices create a 'Dadaeske montage of the Dalek' of academia and at the same time surface an emancipatory bricolage of ideas and praxes that help them de-construct that Dalek.

There are many reasons to start our FSL PGCert module and course in the way that we do. One is our belief in creativity as emancipatory and reparative practice (Sedgwick in Laing, 2020; Sinfield, Burns, Abegglen, 2019) coupled with our perception that typically the pre-tertiary education system with its transactional focus on League Table positions and consequent urge to 'teach to the test' will have worked very successfully to eradicate the creative in most learners (see also Ken Robinson, TED talk, 2006), and thus also in our staff. Working in a predominately widening participation HEI we see staff and students arrive with low self-efficacy and little self-belief. Our 'nontraditional' students in particular are made to feel unwelcome or uncomfortable within $\mathrm{HE}$, where a typical response is to see them as 'deficit' and to devise supplementary programmes or instruction to 'fix' them (Sinfield, Burns and Abegglen, 2019). Concurrently there is a 'rush' to make HE - and academic staff themselves - more successful, efficient and accountable: to strategies and targets, to learning, teaching and assessment frameworks, to ever-evolving policies and practices. Implicit, here, is a concept emerging of a deficit staff that also needs 'fixing' or at least micro-managing (Sinfield, Burns and Holley, 2004).

We do not conceive of our module as a way of 'fixing' staff - nor of preparing them to 'fix' their students. Rather we use creative and visual practices as a way of helping them explore more 'ways of seeing' (Berger, 1972) the educational context(s) in which we all operate. We do hope that being enabled to see and think differently "can be a route to clarity ... a force of resistance and repair, providing new registers, new languages in which to think" (Laing, 2020). As shown through our analysis, our visual practices allow the surfacing and discussing of the problematic nature of HE itself, of the systemic inequities built into the very systems with which our staff and students have to engage. What we attempt is creative action and reflection - opportunities for our participants to actively and critically engage and thus to develop curricula and

International Journal of Management and Applied Research, 2020, Vol. 7, No. 3 
pedagogic practice that better help them and their students to become their whole creative selves. Our staff learners have produced visual representations to envision their own selves. They constructed students and collaboratively built representative HE systems. Their representations acknowledged power (the tower) and pain (the dangerous maze) - but they also showcased opportunities for flexibility, porosity and openness. They 'visualise' where staff sees issues - and potentialities - to develop a new vision of what education could be. Their artefacts constitute acts of hope and of resistance.

\section{References}

1. Abegglen, S., Burns, T., Maier, S. and Sinfield, S. (2020a), "Global university, local issues: Taking a creative and humane approach to learning and teaching", in: Blessinger, P. (eds.), International perspectives on improving classroom engagement and international development programs: Humanizing higher education, (Innovations in Higher Education Teaching and Learning, Vol. 27), Emerald Publishing Limited, pp. 75-91. https://doi.org/10.1108/S2055364120200000027007

2. Abegglen, S., Burns, T., Maier, S. and Sinfield, S. (2020b), "Supercomplexity: Acknowledging students' lives in the 21 st century university", Innovative Practice in Higher Education, Vol. 4, No. 1, pp. 20-38.

3. Abegglen, S., Burns, T. and Sinfield, S. (2018), "Drawing as a way of knowing: Visual practices as the route to becoming academic", Canadian Journal for Studies in Discourse and Writing/Rédactologie, 28, pp. 173-185. https://doi.org/10.31468/cjsdwr.600

4. Bateson G. (2000), Steps to an ecology of mind: Collected essays in anthropology, psychiatry, evolution, and epistemology, Chicago: University of Chicago Press. https://doi.org/10.7208/chicago/9780226924601.001.0001

5. Bearsley, M. (2020), "Don't give me the score", BBC Radio5 Live. Available from: https://www.bbc.co.uk/programmes/m000hj81 [Accessed 23 April 2020].

6. Berger, J. (1972), Ways of seeing, London: British Broadcasting Corporation and Penguin Books.

7. Bernstein, B. (2001), 'From pedagogies to knowledges', In: A. Morais, I. Neves, B. Davies, and H. Daniels (eds). Towards a sociology of pedagogy. The contribution of Basil Bernstein to research, New York: Peter Lang, pp. 363-368.

8. Burns, T., Sinfield, S. and Abegglen, S. (2018), "Re-genring academic writing", Journal of Writing in Creative Practice, Vol. 11, No. 2, pp. 181-303.

9. Elbow, P. (1998), Writing without teachers, 2nd Edition, New York: Oxford University Press.

10. Giroux, H. A. (2014), Neoliberalism's war on higher education, Chicago: Haymarket Books.

International Journal of Management and Applied Research, 2020, Vol. 7, No. 3 
11. Hirst, P. H. (1974), Knowledge and the curriculum: A collection of philosophical papers, London: Routledge and Kegan Paul.

12. Holt, J. (1976), Instead of education, Harmondsworth: Pelican.

13. Huizinga, J. (1949), Homo ludens: A study of the play-element in culture, London: Routledge and Kegan Paul.

14. Illich, I. (1972), Deschooling society, New York: Harper and Row.

15. James, A. and Nerantzi, C. (2019), The power of play in higher education: Creativity in tertiary learning, London: Palgrave Macmillan. https://doi.org/10.1007/978-3-319-95780-7

16. Kay, J. and King, M. (2020), Radical uncertainty: Decision-making beyond the numbers, New York: W. W. Norton and Company.

17. Laing, O. (2020), "Feeling overwhelmed? How art can help in an emergency", The Guardian. Available from: https://www.theguardian.com/books/2020/mar/21/feeling-overwhelmed-how-artcan-help-in-an-emergency-by-olivia-laing [Accessed 23 April 2020].

18. Mason, B. (1993), “Towards positions of safe uncertainty”, Human Systems: The Journal of Systemic Consultation and Management, Vol. 4, No. 3-4, pp. 189-200.

19. McIntosh, P. (2010), Action research and reflective practice: Creative and visual methods to facilitate reflection and learning, London: Routledge. https://doi.org/10.4324/9780203860113

20. McIntosh, P. (2007), "Reflective reproduction: A figurative approach to reflecting in, on, and about action”, Educational Action Research, Vol. 16, No. 1, pp. 125143. https://doi.org/10.1080/09650790701833162

21. Moen, T. (2006), "Reflections on the narrative research approach", International Journal of Qualitative Methods, Vol. 5, No. 4. https://doi.org/10.1177\%2F160940690600500405

22. MoMA (no year), "Dada: Discover how dada artists used chance, collaboration, and language as a catalyst for creativity", MoMA Learning. Available from: https://www.moma.org/learn/moma_learning/themes/dada/chance-creationscollage-photomontage-and-assemblage/ [Accessed 20 April 2020].

23. Nerantzi, C. (2016), "Learning to play, playing to learn: The rise of playful learning in higher education", in: Digifest 2016. Available from: https://www.jisc.ac.uk/news/learning-to-play-playing-to-learn-the-rise-of-playfullearning-in-he-25-feb-2016-inform [Accessed 20 February 2020].

24. Parr, R. (2014), “The importance of play”, Times Higher Education, Available from: $\quad$ https://www.timeshighereducation.com/features/the-importance-ofplay/2012937.article [Accessed 20 February 2020].

25. Richardson, L. and St. Pierre, E. A. (2005), "Writing: A method of inquiry”, In: N. K. Denzin and Y. S. Lincoln (eds.), Handbook of qualitative research, 3rd Edition, Thousand Oaks: Sage, pp. 959-978.

International Journal of Management and Applied Research, 2020, Vol. 7, No. 3 
26. Robinson, K. (2006), "Do schools kills creativity?", TED talk, Available from: https://www.ted.com/talks/sir ken robinson do schools kill creativity?language =en [Accessed 23 April 2020].

27. Rogers, C. (1961), On becoming a person: A therapist's view of psychotherapy, London: Constable.

28. Schön, D. A. (1983), The reflective practitioner: How professionals think in action, London: Basic Books.

29. Shklovsky, V. (2015, translated by Alexandra Berlina), "Art, as device", Poetics Today, Vol. 36, No. 3, pp. 151-174. https://doi.org/10.1215/03335372-3160709

30. Shklovsky, V. (1990), “Art as device”, In: V. Shklovsky (translated by Benjamin Sher), Theory of prose, Champaign: Dalkey Archive Press, pp. 1-14.

31. Sinfield, S., Burns, T. and Abegglen, S. (2019). "Exploration: Becoming playful the power of a ludic module", In: A. James and C. Nerantzi (eds.), The power of play in higher education: Creativity in tertiary learning, London: Palgrave Macmillan, pp. 23-31. https://doi.org/10.1007/978-3-319-95780-7_2

32. Sinfield S.; Burns, T. and Holley, D. (2004), "Outsiders looking in or insiders looking out? Widening participation in a post-1992 university”, In: J. Satterthwaite, E. Atkinson, W. Martin (eds.), The disciplining of education: New languages of power and resistance, Stoke on Trent: Trentham Books, pp. 137-152.

33. Winnicott, D. W. (1971), Playing and reality, London: Tavistock.

International Journal of Management and Applied Research, 2020, Vol. 7, No. 3 